\title{
Influence of Celebrity Endorsement of Advertisement on Students’ Purchase Intention
}

\section{Adeyanju Apejoye*}

Department of mass communication, School of business \& management studies, Abdu gusau polytechnic, Talata mafara, zamfara state, Nigeria

\begin{abstract}
Celebrity endorsement is one of the advertising techniques companies use to create awareness and gain favourable responses about their products and services. This expectation is often not realised as negative image about a celebrity endorser, incongruity of a celebrity endorser with the product being endorsed are all capable of inducing bad responses towards the product rather than the other way round. This study therefore examined the influence of celebrity endorsed advertisement on students' purchase intention employing quasi-experiment as the method of study. Two Pepsi Cola commercials were used with one featuring Osaze Odenwingie as the endorser while the second commercial did not feature any celebrity. Findings of the research suggested that celebrityendorsed advert has a significant influence on students' purchase intention. The study therefore recommends that the various elements involved in producing both celebrity endorsed and non- celebrity endorsed adverts should be carefully mixed together in order to achieve desired results. Likewise, the image of a celebrity before the public should be scrutinized before such a celebrity endorses an advert in order not to cast the product in negative light.
\end{abstract}

Keywords: Celebrity; Endorsement; Congruity; Purchase intention

\section{Introduction}

Advertising is a very strong component of business in any society. It possesses pervasive and persuasive power. Though primarily designed by firms in order to create awareness about goods and services, it also "....encourages the development of new and better products, thereby giving consumers wider varieties of choices" [1]. According to Vivian [2], “... advertising generates most of the operating revenue for newspapers, magazines, television and radio." Initially advertising was used primarily to create awareness about goods or services, but as the line between product differentiation in terms of quality and reliability grows thinner and becomes almost completely blurred as a result of availability of cut edge technology, it also becomes obvious that advertisers employ strategies that will confer credibility and increase the popularity of such a product over the others.

The endorsement of products and services in advertising has become an important and integral aspect of modern day advertising, as it has been found to have the potential of improving the financial returns of companies that use it in their advertisements. According to Erdogan et al. [3], "the effect and relevance of celebrity endorsement as a strategy in marketing communication has gained the attention of serious research in academic circles." Companies spend huge resources on celebrities to endorse their products or sponsored messages on television, radio, newspapers, magazines, billboards, the internet and mobile phones, in the hope that such an endorsement will induce favourable attitudes towards the brand and ultimately affect sales and profits by increasing consumers' preference for the brand [4]. In addition, government and non-governmental organizations use celebrities in public messages targeted towards influencing attitudes.

\section{Statement of research problem}

The aim behind any message is to achieve the purpose for which it was conceived. Companies, civil society organizations and government agencies spend billions of naira annually placing one form of advertisement or the other in the media. Also, companies, in their bid to outsmart one another for consumers' attention, normally deploy various advertisement strategies. Some pay huge amounts of money to celebrities so as to identify themselves with their products. They do this in the hope that such an appearance will instantly produce a trickledown effect of making the product become popular and ultimately influence audience to wish to purchase the product/service.

The reality however is that several products in spite of celebrity endorsement and expensive advert have failed to attract customers attention towards many products. For example, when a celebrity is not accepted, his/her unacceptability may affect the product that he/she identifies with negatively. Miciak and Shanklin [5] suggest that celebrity endorsement may alienate consumers much more than attract them. Also, Till and Shimp [6] assert that companies have no control over celebrities' future behaviour. A good example that will suffice here is the Nigerian Television Authority's news report of 30 December, 2009 of the loss of over $\$ 12$ billion by the shareholders of companies whose advertisements Tiger Woods had endorsed, due to scandals involving him. Lee et al. [7] in their research findings discovered that celebrity endorsement can have a negative effect on purchase intentions, the product and even the celebrity, especially through shadow effects or multiple products endorsement.

Also, there lies uncertainty with respect to returns that companies might be able to garner for a brand as Till and Shimp [6] suggest that negative information about a celebrity is capable of lowering consumers' brand evaluation. Likewise, Liu [8] asserts that advertisers do experience dilemmas over the use of local celebrities for a global brand, as the congruence between the brand and the local endorser sometimes is difficult to establish.

*Corresponding author: Adeyanju apejoye, Department of mass communication School of business \& management studies, Abdu gusau polytechnic, Talata mafara, zamfara state, Nigeria, Tel: +2348039656954, +2348094702572; E-mail: ademike2000@yahoo.com

Received February 20, 2013; Accepted March 18, 2013; Published March 25 , 2013

Citation: Apejoye A (2013) Influence of Celebrity Endorsement of Advertisemen on Students' Purchase Intention. J Mass Communicat Journalism 3: 152 doi:10.4172/2165-7912.1000152

Copyright: (c) 2013 Apejoye A. This is an open-access article distributed unde the terms of the Creative Commons Attribution License, which permits unrestricted use, distribution, and reproduction in any medium, provided the original author and source are credited. 
Furthermore, gauging the effectiveness of an endorsed advertisement in correspondence with the volume of sales, the popularity of the product and above all its acceptance by the audience has always been a subject of debate. Spokespersons or celebrities are often seen as possessing expert power, referent power and legitimate power to influence the behaviour of others [9]. However, the question has always been there as to whether a company with a global brand can use a celebrity with a global appeal to win consumers' favour towards its brand in a society where the celebrity has no cultural congruence.

Likewise, the appearance of a celebrity may not guarantee effective advertisement, especially if there is no correlation or congruence between a celebrity and the endorsed brand [10]. An example of this is the endorsement of Harpic Toilet Cleanser by Nkem Owoh popularly known as Osuofia in Nigerian movie industry. The producer of Harpic, Reckit and Benkiser did not record any remarkable response from consumers because the advertisement was a mismatch as washing of toilet traditionally is not done by men in Africa and this in the long run affected the attitudes of consumers towards the product [11]. Also, Guinness Extra Smooth Beer refused to renew the endorsement contract it has with 2 face Idibia due to the latter's sexual escapades for the fear that it may have negative effect on its brand and ultimately affects its credibility [12]. As a result, most organisations are faced with the problem of determining criteria and the best way(s) of using celebrities to endorse their product in such a manner as to produce desired results. Similarly, misfit between an endorser and the product being endorsed in terms of the inability of consumers to identify endorser's quality with the product being advertised is an issue of concern in celebrity endorsement. While celebrity endorsement is good, it can have a negative impact on a product/service because of:

\section{- Mismatch between endorser and product}

Issues/negative impression about celebrity can affect or be transferred to the product endorsed.

\section{Literature Review}

The huge investments of companies in advertising are not without motives, as companies try to outsmart each other with their advertisements in order to obtain a domineering share and win customers' favour. In the United States of America, for instance, 20\% of all commercials incorporate a celebrity endorser [13]. In Nigeria, celebrities especially in the fields of sports and entertainment appear regularly in advertisements endorsing various products. Several examples abound such as Austin Okocha's endorsement of 'Chi Soya Milk', Genevieve Nnaji (Lux), Banky W (Etisalat), Dakore Egbuson (Amstel), etc. Norr and Serena [14] are of the opinion that celebrity endorsement strategy in advertising is a valuable strategy that can reflect the growth of a variety of products ranging from entertainment, sports, food and business, to politics. Byrne [15] argues that

... a celebrity can build, refresh and add new dimensions.

What celebrities stand for enhances a brand and they

save valuable time in terms of creating the credibility

a company has created in order to build its brand by

transferring the values to the brand. When consumers

see a credible celebrity endorse a product, they think the

company must be okay.

In fact, research has shown that people are likely to patronise products and services endorsed by celebrities than those that are not $[16,17]$. As a result, most advertisers indulge in the use of personalities that enjoy public acceptance and credibility to appear in the adverts and endorse their product, as most believe that it can heighten product identification among consumers, facilitate audience recall, and influence the purchase intentions of consumers. Friedman and Friedman [18] and Tripp et al. [19] in their various findings assert the effectiveness of celebrity endorsement as a veritable strategy in influencing consumers to have favourable attitudes towards products endorsed by celebrities.

Celebrity endorsement as a strategy confines legitimacy on and ensures the stability of the social order [20]. Jackson and Darrow [21] and Rapport et al. [22] conducted research on the endorsement effect in politics, and it was discovered that a celebrity that enjoys huge popularity has great influence on voters' manner of voting.

Celebrities, according to Mccraken [23] and Silvera and Austad [24], are people who enjoy public recognition possessing such attributes as attractiveness and trustworthiness. The import of this assertion is that celebrities are people who have excelled in their respective fields of endeavours and therefore command respect, acceptance, popularity and followership within their societies. Likewise, an endorser is a person who makes a 'testimonial', or a written or a spoken statement extolling the virtue of a product. Sanchez [25] sees an endorser as a "person who willingly supports or appears with a product or service in a way that is communicable to the public".

Buttressing the above argument further; Tom et al. [9] assert that spokespersons (endorsers) possess "expert power, referent power and legitimate power". They add that the amount of these powers determines the extent to which behaviours of others are influenced. Knott and James [26] maintain that the attractiveness of endorsers influences the effectiveness of a message. This implies that certain features in a celebrity are capable of making the product he or she endorses become acceptable and have a favourable image. Such attractiveness could be physical such as the facial appearance, height or physique of the celebrity. Similarly, McGuire [27] argues that the effectiveness of an endorsed advert depends on the level to which endorsers are similar and likeable to the audience. Kamins and Gupta [28] however argue that endorsers have the power to heighten the appeal of advertisements due to their attractiveness as Charbonneau and Garland [29] say that celebrity endorsement is a valuable promotional strategy provided there is a fit between celebrity, brand and message. Taking it further, posits that culture road block often experienced by advertisers can be manipulated by using celebrity with worldwide reputation.

Celebrities are also, according to Eerie and Sejung [30], associated with high status due to widespread recognition, and so using a credible and respected celebrity as the voice or message carrier is more effective than using an ordinary model [29]. However, Friedman and Friedman [18] argue that celebrity endorsement of a product that demonstrates the presence or lack of good taste produces better results than that endorsed by an expert or a typical consumer. Celebrities give meaning to an advert with extra subtlety, depth and power. Although an advertisement that features an anonymous model may provide demographic information i.e. gender, age, status, etc., it is often relatively vague and imprecise. However, celebrities offer such information with precision.

\section{Theoretical framework}

The theoretical background for this study is situated within Source 
Effects Models. The source effect models “... posit that certain perceived characteristics of a communication source may have a positive effect on the audience's reception to the conveyed message" [31]. The 'source' in the model refers to the person who originates or conveys a message within the realm of this research; the source means the endorser of an advertisement. The model has two strands, namely: Source Credibility and Source Attractiveness.

Source credibility model: This strand of source effect models explains that the acceptance and favourable response to an advertising message depends on the perception the audience have about the expertise, trustworthiness and knowledge of the source [31,32]. It is also about the communicator's positive characteristics that can influence the receiver's acceptance of a message [33]. Goldsmith et al. [34] argue that source credibility is the "extent to which the source is perceived as possessing expertise relevant to the communication topic and can be trusted to give an objective opinion on the subject". When the source (the endorser) in an advertisement has a very high level of expertise in the area being advertised, his ability to make valid assertion about the product increases (McCracken 1989). Expertise as one of the components of the source credibility model implies that the knowledge and experience of the endorser on the product being advertised affects the acceptability of the product. Where the endorser appears to have a considerable knowledge and experience about the product being advertised, this elicits a favourable attitude from consumers (Ohanian, 1990). Trustworthiness as another attribute of the Source Credibility Model against expertise means that a celebrity needs to possess the quality of trustworthiness in order for an advert to achieve desired results in consumers (Schiffman and Kanuk, 2004). The import is that the targeted audience must find the endorser honest enough concerning what he says about the brand in order to be convinced.

Source Attractiveness Model: This part of the source effect models means that the acceptance of an advertising message by the audience is based on familiarity, likeability and similarity. McCracken [23] provides more insight about the meaning of the three major concepts that uphold the source attractiveness model by saying "familiarity is defined as knowledge of the celebrity through exposure in the media; likeability as affection for the celebrity as a result of the celebrity's physical appearance and/or behaviour; and similarity as a supposed resemblance between the celebrity and the targeted audience".

- In fact, the physical attractiveness of a celebrity can be said to be the most emphasized in an advert, as it elicits greater social acceptance [35] and produces a positive impression at the initial social contact [36]. This explains why such attributes of physical attractiveness like beauty, physique and sex appeal are common in any advert featuring a celebrity endorsement.

\section{Hypotheses}

\section{The following hypotheses are formulated for this research:}

H1 Celebrity endorsed advertisements do not significantly impact on buyers purchase intent.

H2 Celebrity endorsement does not significantly increase the popularity and credibility of a product.

H3 Recall level of advertisement that is endorsed is not significantly higher than the one that is not endorsed.

\section{Research design}

This research adopted the Quasi- experiment research method.
Quasi- experiment research method, according to Stacks and Hockings [37] is a broad term that refers to any study in which, although one or more features of a true experiment are not present, the effect of an independent variable is structured by making comparisons between groups exposed to different levels of independent variables. Quasiexperiment relaxes the probabilistic and population distribution conditions imposed by true experiment research designs by shifting the emphasis from 'cause-effect' in temporal priority to 'association' between variables. The researcher adopted quasi-experiment method because it will assist in reducing threats to external validity as participants in the research are drawn from their natural environment hence, will not suffer the problems of artificiality often experienced in a well controlled laboratory setting. Participants were exposed to two types of television commercials. The two commercials are for PepsiCola brand of soft drink. The first Pepsi-cola commercial featured a sport celebrity by the name Osaze Odenwigwe who is a professional footballer while the second commercial did not have the endorsement of any celebrity in it. The commercial for Pepsi-Cola that had the appearance of Osaze Odenwingwe were exposed to the participants in group A referred to as the experimental group while another commercial for Pepsi that did not have any endorser in it were exposed to group B referred to as the control group of the research. The relevant commercial for the two groups were exposed to the groups through a multi-media projector after which the respondents were given a prepared questionnaire to complete.

\section{Population of Study}

The population of study for the research are the students of Abdu Gusau Polytechnic, Zamfara state. The total population of students of the school is estimated around three thousand and eight hundred $(3,800)$ while the school has sixteen (16) departments. The regular students' population is 1,200; the population for part time diploma and higher national diploma students is 1,800 while the population for post graduate diploma students is 800 . The age group of the population of study ranged from 16 to 45 years and comprised of male and female.

\section{Sampling technique}

The researcher adopted two sampling techniques for this study. The four departments out of the sixteen departments in the school from which sample population are drawn were selected through simple random sampling method while systematic sampling technique was used to select the population that participated in the experiment. To draw the four departments, the researcher wrapped sixteen papers each containing the name of different departments into a bowl out of which four were picked at random and the reason for picking the four is borne out of the fact that the total population is too large for the researcher to investigate all hence, the need to randomly pick the four since the departments picked have the characteristics of the population relevant to the study.

\section{Sample size}

To examine the influence of celebrity endorsement on students purchase intention, a total of 120 regular students from the four departments sampled divided into two groups participated in the study. Group a comprising 60 students were used as the experimental group while Group B comprising 60 students served as the control group. This figure was arrived at by using $10 \%$ of the population. According to Nwanna [38], "10\% will do for a research population in few thousands", and Gay [39] recommends a minimum of $10 \%$ for a descriptive research. The total population for the four departments 
Citation: Apejoye A (2013) Influence of Celebrity Endorsement of Advertisement on Students' Purchase Intention. J Mass Communicat Journalism 3: 152. doi:10.4172/2165-7912.1000152

Page 4 of 7

selected was one thousand and two hundred. The population for mass communication department is two hundred and fifty (250), accounting department is four hundred (400), Science laboratory department is one hundred and twenty (120) while business administration department has a population of Four hundred and thirty (430). To make the sampling selection scientific, the researcher employed systematic sampling method to draw the one hundred and twenty (120) sample size as according to Ogbuoshi [40], "systematic sampling method is to be applied only if the given population is logically homogenous." Using the formula below, every $10^{\text {th }}$ number in the sampling frame is included in the sample size.

$$
\mathrm{k}=\mathrm{N} / \mathrm{n}
$$

Where $\mathrm{k}=$ Sampling interval

\section{$\mathrm{N}=$ Population size}

$\mathrm{n}=$ Sample size

where $\mathrm{N}=1200$

and $\mathrm{n}=120$

Therefore $1200 / 120=10$

Therefore $\mathrm{k}=10$.

\section{Test of hypotheses}

H1: Celebrity endorsed advertisement does not significantly impact on buyers purchase intent.

A one pair sample test was run for experimental and controlled group and the result for each group is shown below Tables 1a-1d:

From the above results for experimental group, the alpha level is

\begin{tabular}{|l|l|l|l|l|}
\hline & $\mathrm{N}$ & Mean & $\begin{array}{l}\text { Std. } \\
\text { Deviation }\end{array}$ & $\begin{array}{l}\text { Std. Error } \\
\text { Mean }\end{array}$ \\
\hline $\begin{array}{l}\text { The information in the commercial is } \\
\text { appropriate and should influence my } \\
\text { buying decision }\end{array}$ & 40 & 4.4333 & .76727 & .09905 \\
\hline $\begin{array}{l}\text { Overall, after watching the commercial, } \\
\text { I begin to like this brand }\end{array}$ & 60 & 1.0000 & .18411 & .02377 \\
\hline $\begin{array}{l}\text { I believed the claims made by the } \\
\text { product in the advertisement }\end{array}$ & 60 & 4.4667 & 1.11183 & .14354 \\
\hline $\begin{array}{l}\text { Would you decide to buy the product } \\
\text { because the celebrity endorsed it? }\end{array}$ & 60 & 1.0167 & .29063 & .03752 \\
\hline
\end{tabular}

Table 1a: Experimental Group-One-Sample Statistics.

\begin{tabular}{|l|l|l|l|l|l|l|}
\hline & \multicolumn{3}{|l|}{ Test Value=0 } & \multicolumn{2}{l|}{} \\
\cline { 2 - 7 } & T & Df & $\begin{array}{l}\text { Sig. } \\
\text { (2-tailed) }\end{array}$ & $\begin{array}{l}\text { Mean } \\
\text { Difference }\end{array}$ & $\begin{array}{l}95 \% \text { Confidence } \\
\text { Interval of the } \\
\text { Difference }\end{array}$ \\
\hline $\begin{array}{l}\text { The information in the } \\
\text { commercial is appropriate } \\
\text { and should influence my } \\
\text { buying decision }\end{array}$ & 44.757 & 59 & .000 & 4.43333 & 4.2351 & 4.6315 \\
\hline $\begin{array}{l}\text { Overall, after watching the } \\
\text { commercial, I begin to like } \\
\text { this brand }\end{array}$ & 42.071 & 59 & .000 & 1.00000 & .9524 & 1.0476 \\
\hline $\begin{array}{l}\text { I believed the claims } \\
\text { made by the product in } \\
\text { the advertisement }\end{array}$ & 31.119 & 59 & .000 & 4.46667 & 4.1795 & 4.7539 \\
\hline $\begin{array}{l}\text { Would you decide to buy } \\
\text { the product because the } \\
\text { celebrity endorsed it? }\end{array}$ & 27.097 & 59 & .000 & 1.01667 & .9416 & 1.0917 \\
\hline
\end{tabular}

Table 1b: Experimental Group-One-Sample Test.

\begin{tabular}{|l|l|l|l|l|}
\hline & N & Mean & $\begin{array}{l}\text { Std. } \\
\text { Deviation }\end{array}$ & $\begin{array}{l}\text { Std. Error } \\
\text { Mean }\end{array}$ \\
\hline $\begin{array}{l}\text { The information in the commercial is } \\
\text { appropriate and should influence my } \\
\text { buying decision }\end{array}$ & 60 & 2.4167 & 1.13931 & .14708 \\
\hline $\begin{array}{l}\text { Overall, after watching the } \\
\text { commercial, I begin to like this brand }\end{array}$ & 60 & 1.9667 & .86292 & .11140 \\
\hline $\begin{array}{l}\text { I believed the claims made by the } \\
\text { product in the advertisement }\end{array}$ & 60 & 2.3500 & 1.25988 & .16265 \\
\hline $\begin{array}{l}\text { Would you decide to buy the product } \\
\text { because the celebrity endorsed it? }\end{array}$ & 60 & 1.7833 & 1.22255 & .15783 \\
\hline
\end{tabular}

Table 1c: Controlled Group-One-Sample Statistics.

\begin{tabular}{|l|l|l|l|l|l|l|}
\hline & \multicolumn{5}{|l|}{ Test Value=0 } \\
\cline { 2 - 7 } & T & Df & $\begin{array}{l}\text { Sig. } \\
\text { (2-tailed) }\end{array}$ & $\begin{array}{l}\text { Mean } \\
\text { Difference }\end{array}$ & $\begin{array}{l}\text { 95\% Confidence } \\
\text { Interval of the } \\
\text { Difference }\end{array}$ \\
\hline $\begin{array}{l}\text { The information in } \\
\text { the commercial is } \\
\text { appropriate and should } \\
\text { influence my buying } \\
\text { decision }\end{array}$ & 16.431 & 59 & .000 & 2.41667 & 2.1224 & 2.7110 \\
\hline $\begin{array}{l}\text { Overall, after watching } \\
\text { the commercial, I begin } \\
\text { to like this brand }\end{array}$ & 17.654 & 59 & .000 & 1.96667 & 1.7438 & 2.1896 \\
\hline $\begin{array}{l}\text { I believed the claims } \\
\text { made by the product in } \\
\text { the advertisement }\end{array}$ & 14.448 & 59 & .000 & 2.35000 & 2.0245 & 2.6755 \\
\hline $\begin{array}{l}\text { Would you decide } \\
\text { to buy the product } \\
\text { because the celebrity } \\
\text { endorsed it? }\end{array}$ & 11.299 & 59 & .000 & 1.78333 & 1.4675 & 2.0992 \\
\hline
\end{tabular}

Table 1d: Controlled Group-One-Sample Test.

0.05 or $\mathrm{p}<.05$ meaning that the result would happen no more that $5 \%$ of the time (so 1 time in 20 samples) was used to either accept or reject the null hypothesis. Since $t(59)=44.757,42.071,31.119$ and 27.097 for each of the questions tested while the $P$ value for each question is $=.000$ respectfully; it means the result is statistically insignificant because the calculated value fall below the $\mathrm{p}$ value or alpha value. Thus, the null hypothesis is rejected and the alternate accepted, hence a celebrity endorsed advertisement does have significant impact on the intent to purchase a product.

For controlled group, the alpha level is 0.05 or $\mathrm{p}<.05$ meaning that the result would happen no more that $5 \%$ of the time (so 1 time in 20 samples) was used to either accept or reject the null hypothesis. Since $t(59)=16.431,17.654,14.448$ and 11.299 for each of the questions tested while the $\mathrm{P}$ value for each question is $=.000$ respectfully; it means the result is statistically insignificant because the calculated value fall below the $\mathrm{p}$ value or alpha value. Thus, from the foregoing we reject the null and also accept the alternative. Hence, a celebrity endorsed advertisement does have significant impact on intent to purchase a product.

H2: Celebrity endorsement does not significantly increase the popularity and credibility of a product.

A question was raised to test the hypothesis while one pair sample test was run for both experimental and control groups and the result are shown below Tables $2 \mathrm{a}$ and $2 \mathrm{~d}$.

From the above results for experimental group, the alpha level of 0.05 or $\mathrm{p}<.05$ meaning that the result would happen no more that $5 \%$ of the time (so 1 time in 20 samples) was used to either accept or reject the null hypothesis. Since $t(59)=31.119, \mathrm{P}=.000$. The result is statistically 
Citation: Apejoye A (2013) Influence of Celebrity Endorsement of Advertisement on Students' Purchase Intention. J Mass Communicat Journalism 3: 152. doi:10.4172/2165-7912.1000152

\section{One-Sample Statistics}

\begin{tabular}{|l|l|l|l|l|}
\hline & N & Mean & $\begin{array}{l}\text { Std. } \\
\text { Deviation }\end{array}$ & $\begin{array}{l}\text { Std. Error } \\
\text { Mean }\end{array}$ \\
\hline $\begin{array}{l}\text { I believed the claims made by the } \\
\text { product in the advertisement }\end{array}$ & 60 & 4.4667 & 1.11183 & .14354 \\
\hline
\end{tabular}

Table 2a: Experimental Group-One-Sample Statistics.

\begin{tabular}{|l|l|l|l|l|l|l|}
\hline One-Sample Test & \multicolumn{9}{l|}{ Test Value=0 } \\
\hline & T & Df & $\begin{array}{l}\text { Sig. } \\
\text { (2-tailed) }\end{array}$ & $\begin{array}{l}\text { Mean } \\
\text { Difference }\end{array}$ & $\begin{array}{l}\text { 95\% Confidence } \\
\text { Interval of the } \\
\text { Difference }\end{array}$ \\
\hline & & & & & Lower & Upper \\
\hline $\begin{array}{l}\text { I believed the claims } \\
\text { made by the product in } \\
\text { the advertisement }\end{array}$ & 31.119 & 59 & .000 & 4.46667 & 4.1795 & 4.7539 \\
\hline
\end{tabular}

Table 2b: Experimental Group-One-Sample Test.

\begin{tabular}{|l|l|l|l|l|}
\hline One-Sample Statistics & N & Mean & $\begin{array}{l}\text { Std. } \\
\text { Deviation }\end{array}$ & $\begin{array}{l}\text { Std. Error } \\
\text { Mean }\end{array}$ \\
\hline $\begin{array}{l}\text { I believed the claims made by the } \\
\text { product in the advertisement }\end{array}$ & 60 & 2.3500 & 1.25988 & .16265 \\
\hline
\end{tabular}

Table 2c: Controlled Group-One-Sample Statistics.

\begin{tabular}{|l|l|l|l|l|l|l|}
\hline One-Sample Test & \multicolumn{5}{|c|}{ Test Value=0 } \\
\cline { 2 - 8 } & T & Df & $\begin{array}{l}\text { Sig. } \\
\text { (2-tailed) }\end{array}$ & $\begin{array}{l}\text { Mean } \\
\text { Difference }\end{array}$ & $\begin{array}{l}\text { 95\% Confidence } \\
\text { Interval of the } \\
\text { Difference }\end{array}$ \\
\hline $\begin{array}{l}\text { I believed the claims } \\
\text { made by the product in } \\
\text { the advertisement }\end{array}$ & 14.448 & 59 & .000 & 2.35000 & 2.0245 & 2.6755 \\
\hline
\end{tabular}

Table 2d: Controlled Group-One-Sample Test.

insignificant because the calculated value falls below the $\mathrm{p}$ value or alpha value. Thus, from the foregoing we reject the null and accept the alternative. Hence, celebrity endorsement does significantly increase the popularity and credibility of a product.

From the controlled group results, the alpha level of 0.05 or $\mathrm{p}$ $<.05$ meaning that the result would happen no more that $5 \%$ of the time (so 1 time in 20 samples) was used to either accept or reject the null hypothesis. Since $t(59)=14.448, \mathrm{P}=.000$. The result is statistically insignificant because the calculated value falls below the $\mathrm{p}$ value or alpha value. Thus, from the foregoing the null hypothesis is rejected and alternative accepted. Therefore, celebrity endorsement of advertisement does significantly increase the popularity and credibility of a product.

H3: Recall level of advertisement that is endorsed is not significantly higher than the one that is not endorsed.

A one pair sample test was run for both experimental and controlled groups and the result are shown in Tables 3a-3d.

From the above results, the alpha level of 0.05 or $\mathrm{p}<.05$ meaning that the result would happen no more that $5 \%$ of the time (so 1 time in 20 samples) was used to either accept or reject the null hypothesis. Since $t(59)=17.897, \mathrm{P}=.000$. The result is statistically insignificant because the calculated value fall below the $\mathrm{p}$ value or alpha value. Thus, from the foregoing the null hypothesis is rejected and the alternate accepted. Therefore, recall level of advertisement that is endorsed is significantly higher than the one that is not endorsed.
For the controlled group result, the alpha level of 0.05 or $\mathrm{p}<.05$ meaning that the result would happen no more that $5 \%$ of the time (so 1 time in 20 samples) was used to either accept or reject the null hypothesis. Since $t(59)=11.531, \mathrm{P}=.000$. The result is statistically insignificant because the calculated value fall below the $\mathrm{p}$ value or alpha value. Thus, from the foregoing the null hypothesis is rejected and therefore, recall level of advertisement that is endorsed is significantly higher than the one that is not endorsed

\section{Discussion of Findings}

The aim of this study was to find out the influence of celebrity endorsement on Students' Purchase Intention. Using source effect model as theoretical background for the research and an extensive review of literature related to the topic; hypotheses were formulated and tested and in the process, several findings were made.

\section{Hypothesis 1}

Celebrity endorsed advertisement do not significantly impact on buyers purchase intent.

Findings: The result of the study did not support the hypothesis and suggested that celebrity endorsed advertisement does significantly impact on buyers' purchase intent. Although, the research findings support Knott \& James (2003:9) that "the attractiveness of endorsers influences the effectiveness of a message." It is not however the only reason for influencing students' consumers' purchase intention as the study demonstrated that other factors like music and graphics in

\begin{tabular}{|l|l|l|l|l|}
\hline \multicolumn{7}{|c|}{ One-Sample Statistics } \\
\hline & N & Mean & $\begin{array}{l}\text { Std. } \\
\text { Deviation }\end{array}$ & $\begin{array}{l}\text { Std. Error } \\
\text { Mean }\end{array}$ \\
\hline $\begin{array}{l}\text { Mention two most attractive objective } \\
\text { you saw in the commercial }\end{array}$ & 60 & 1.2667 & .54824 & .07078 \\
\hline
\end{tabular}

Table 3a: Experimental Group-One-Sample Statistics.

\begin{tabular}{|l|l|l|l|l|l|l|}
\hline One-Sample Test & \multicolumn{9}{l|}{} \\
\hline & Test Value=0 & Df & $\begin{array}{l}\text { Sig. } \\
\text { (2-tailed) }\end{array}$ & $\begin{array}{l}\text { Mean } \\
\text { Difference }\end{array}$ & $\begin{array}{l}\text { 95\% Confidence } \\
\text { Interval of the } \\
\text { Difference }\end{array}$ \\
\hline & T & & & Lower & Upper \\
\hline $\begin{array}{l}\text { Mention two most } \\
\text { attractive objective you } \\
\text { saw in the commercial }\end{array}$ & 17.897 & 59 & .000 & 1.26667 & 1.1250 & 1.4083 \\
\hline
\end{tabular}

Table 3b: Experimental Group-One-Sample Test.

\begin{tabular}{|l|l|l|l|l|}
\hline One-Sample Statistics & N & Mean & $\begin{array}{l}\text { Std. } \\
\text { Deviation }\end{array}$ & $\begin{array}{l}\text { Std. Error } \\
\text { Mean }\end{array}$ \\
\hline $\begin{array}{l}\text { Mention two most attractive features } \\
\text { you saw in the commercial }\end{array}$ & 60 & 1.3333 & .89569 & .11563 \\
\hline
\end{tabular}

Table 3c: Controlled Group-One-Sample Statistics.

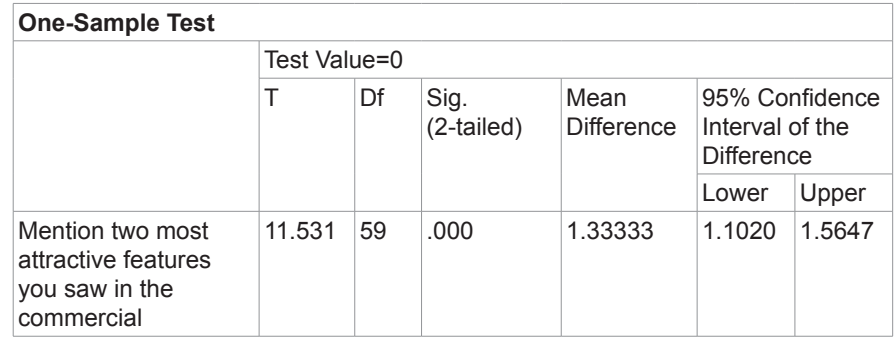

Table 3d: Controlled Group-One-Sample Test. 
a commercial equally played significant role in influencing students' consumers' intention. This finding also showed that consumers are also influenced by simple cues such as attractive slogans, music or imagery in a commercial instead of close scrutiny of the message.

\section{Hypothesis 2}

Celebrity endorsement does not significantly increase the popularity and credibility of a product.

Findings: The results of the study did not support this hypothesis and suggested that an endorsed advert by a celebrity does significantly increase the popularity and credibility of the product than when the product advert is not endorsed. The research findings indicated that a well-known and well-liked personality within the society evokes likeness and good image towards a product or services."

The finding also buttressed the source credibility model which explains that the acceptance and favourable response to an advertisement message depends on the perception the audience have about the expertise, trustworthiness and knowledge of the source. From the study, it was revealed that the credibility the brand has in the minds of the consumers has to do with the fact that the celebrity is a popular person. Also, the findings revealed that the celebrity is not a controversial person and therefore, they will buy the brand.

The findings also show that expertise and the popularity of an endorser are capable of increasing information processing among consumers.

\section{Hypothesis 3}

Recall level of advertisement that is endorsed is not significantly higher than the one that is not endorsed.

Findings: Hypothesis 3 tested the recall level of advertisement that is endorsed by a celebrity and the one that is not by a celebrity. Results of the findings did not support the hypothesis. Results indicated that the level of recall by students' consumers for commercial endorsed by a celebrity is significantly higher over commercial that is not endorsed. Findings also revealed that the presentation of a spokesperson will significantly increase the likelihood that the product name will be called to mind. The message carried in the advertisement also played an important factor in the consumers' ability to recall the advertisement. Likewise, the research indicated that the graphics in the advertisement had a lasting impression on the minds of the consumers and enhances their recall ability.

\section{Conclusion and Recommendation}

Despite all the limitations mentioned, the study has shown that celebrity endorsement is an area in advertising that is worth thorough investigation as huge resources are expended by companies on advertisement annually. It appears from the research findings that celebrity endorsement of advertisement does have significant influence on students' consumers over an advertisement that is not endorsed. It can be inferred from the findings of the research that the acceptability of a product as a result of its commercial is due to celebrity's endorsement of the product with various intermingling factors such as music and graphics playing complementary roles. Since the findings of the research suggested that celebrity endorsed advert has significant influence on students' consumers purchase intention and also that other variables like music and graphics do play complementary roles in such influence; the researcher therefore recommends that:

1. Care must be taken to scrutinize a celebrity's lifestyle and his present social acceptance before endorsement so as to avoid any negative image or scandals that could have negative effect on the product.

2. It is also recommended that advertisers while producing an advert should consider apart from the messages, simple cues like interesting slogans, good graphics and music that consumers can easily identify and empathized with in order for them to comprehend the advert better and have favourable response towards it.

3. Cultural, social and psychological factors such as age, lifestyle, personality, credibility, prowess, etc. should be carefully looked at about an endorser and in turn weave it round a commercial in such a way that consumers can identify with it.

4. Advertisers should also ensure before using a celebrity to endorse their product that there is a level of congruence between an endorser and the product to be endorsed. This is to avoid a situation where the public image and acceptance of an endorser overshadows the product endorsed or what is termed vampire effect.

\section{References}

1. Osunbiyi B (1999) Advertising Principles and Practice. Abeokuta: Gbenga Gbesan Publishers.

2. Vivian J (2009) The Media of Mass Communication. Boston: Pearson

3. Erdogan B, Baker M, Taggs (2000) Selecting Celebrity Endorsers: The Practitioner's Perspective. Journal of Consumer Research 41: 39-48.

4. Nam-Hyun U (2008) Exploring the effects of Single vs. Multiple Celebrity Endorsement. Journal of Management and Social Science 4: 104-114.

5. Miciak AR, Shanklin WL (1994) Choosing Celebrity Endorsers. Marketing Management 3: 50-59.

6. Till BD, Shimp TA (1994) Endorsers in Advertising: The Case of Negative Celebrity Information. Journal of Advertising 27: 67-82.

7. Lee WN, Pack J, Kim HJ (2004) Lessons from the rich and famous. Journal of Advertising 35: 85-98.

8. Liu Y (2001) What is Interactivity and is it always such a good thing? Implications of definition, person, and situation for the influence of interactivity on advertising effectiveness. Journal of Advertising 31: 53-64.

9. Tom G, Clark R, Elmer L, Grech E, Massetti J (1992) The Use of Celebrity Spokespersons in Advertisement. The Journal of consumer Marketing 9: 45-51.

10. Kahle LR, Homer PM (1985) Physical Attractiveness of the Celebrity Endorser A Social Adaptation Perspective. Journal of Consumer Research 11: 954-961.

11. Adebija A (2010) As Celebrity winds of endorsement sweep the land. Daily Independent October 29, 2010.

12. Durojaiye A (2009) Between Celebrity Endorsement and Brand Building. Daily Sun January, 13, 2010.

13. Bradley N (1996) Marketing Research, Tools and Techniques. Oxford: University Press.

14. Norr, Serena (2007) The Power of Celebrity Endorsement. Tea and Coffee Trade Journal 4: 179

15. Byrne AW, Breen MS (2003) The Naked Truth of Celebrity Endorsement. British Food Journal 105: 288-296.

16. Agrawal J, Kamakura WA (1995) The Economic Worth of Celebrity Endorsers: An Event Study Analysis. Journal of marketing 59: 56-62

17. Dyson A, Turco D (1998) The State of Celebrity Endorsement in Sports. The cyber Journal of Sport Marketing. Retrieved on Sept. 28.

18. Friedman HH, Friedman L (1979) Endorsers Effectiveness by Product Type Journal of Advertising Research 19: 63-71.

19. Tripp C, Jenson TD, Carlson L (1994) The effects of Multiple Product Endorsement by Celebrities on Consumer Attitudes and Intentions. Journal of Consumer Research 20: 53-54. 
Citation: Apejoye A (2013) Influence of Celebrity Endorsement of Advertisement on Students' Purchase Intention. J Mass Communicat Journalism 3: 152. doi:10.4172/2165-7912.1000152

Page 7 of 7

20. Walker M, Thomas B, Zeldith R (1986) Celebrity Endorsers: Do you get what you paid for? Journal of Consumer Marketing 9: 69-76.

21. Jackson DJ, Darrow TA (2005) The Influence of Celebrity Endorsement on Young Adults' Political Opinions. Press/Politics 10: 80-98.

22. Rapport RB, Stone WJ, Abramowitz A (1991) Do Endorsements Matter? Group Influence in the 1984 Democratic Caucuses. American Political Science Review 85: 193-203.

23. Mccracken G (1989) Who is the Celebrity Endorsers? Cultural foundations of the celebrity endorsement Process. Journal of Consumer Research 16: 310 321

24. Silvera DH, Austad B (2004) Factors predicting the effectiveness of celebrity endorsement advertising. European Journal of Marketing 38: 1509-1526.

25. Sanchez R (2004) Creating Modular Platform for Strategic Flexibility. Design Management Review Winter 58-67.

26. Knott O, James L (2003) An Alternative Approach to Developing a Total Celebrity Endorser Rating Model Using the Analytic Hierarchy Process. International Transactions in Operational Research 23-34.

27. McGuire W (1984) Search for the Self: Going beyond Self-Esteem and the Reactive Self. In R.A. Zucker., J. Aronoff, \& A.I. Rabin (Eds), Personality and the Prediction of Behaviour. New York: Academy Press.

28. Kamins M, Guptp K (1994) Congruence between Spokespersons and Product Type: A Match-up Hypothesis Perspective. Psychology and Marketing 2: 569 586.

29. Charbonneau J, Garland R (2005) Product Effects on Endorser Image: The Potential for Reverse Image Transfer. Asia Pacific Journal of Marketing and Logistics 22: 101-110.
30. Eerie C, Sejung CM (2005) The Subject of Celebrity Endorsement: What it was and what it has become. An unpublished thesis of Luka University of Tech.

31. Erdogan B (1999) Celebrity Endorsement: A Literature Review. Journal of Marketing Management 15: 291-314.

32. O' Mahony S, Meenaghan T (1998) The Impact of Celebrity Endorsement on Consumer. Irish Marketing Review 10: 15-24.

33. Ohanian R (1991) The Impact of Celebrity Spokespersons Perceived Image on Consumer Intention to Purchase. Journal of Advertising Research 2: 46-54.

34. Goldsmith ER, Lafferty AB, Newell JS (2000) The Impact of Corporate Credibility and Celebrity credibility on consumer reaction to advertisement and brands. Journal of Advertisin 29: 3.

35. Kleck RE, Richardson SA, Ronald L (1974) Physical Appearance Cues and Interpersonal Attraction in Children. Child Development 45: 305-310.

36. Miller AG (1970) The Role of Physical Attractiveness in Impression Formation Psychometric Science 19: 241-243.

37. Stacks DW, Hockings JE (1999) Communication Research. New York: AdisonWesley.

38. Nwanna OC (1981) Introduction to Educational Research for Student Teachers Ibadan: Heinemann.

39. Gay L (1981) Research in Education. London: Oldham.

40. Ogbuosi LI (2006) Understanding Research Methods and Thesis Writing Enugu: Linco Enterprises. 